\title{
DIFFERENT PATTERNS OF PARENTAL EFFORT DURING CHICK- REARING BY FEMALE AND MALE THICK-BILLED MURRES (URIA LOMVIA) AT A LOW-ARCTIC COLONY
}

\author{
Author(s): Ian L. Jones, Sherrylynn Rowe, Steve M. Carr, Gail Fraser, and Philip Taylor \\ Source: The Auk, 119(4):1064-1074. 2002. \\ Published By: The American Ornithologists' Union \\ DOI: http://dx.doi.org/10.1642/0004-8038(2002)119[1064:DPOPED]2.0.CO;2 \\ URL: http://www.bioone.org/doi/full/10.1642/0004-8038\%282002\%29119\%5B1064\%3ADPOPED \\ $\% 5 \mathrm{D} 2.0 . \mathrm{CO} \% 3 \mathrm{~B} 2$
}

BioOne (www.bioone.org) is a nonprofit, online aggregation of core research in the biological, ecological, and environmental sciences. BioOne provides a sustainable online platform for over 170 journals and books published by nonprofit societies, associations, museums, institutions, and presses.

Your use of this PDF, the BioOne Web site, and all posted and associated content indicates your acceptance of BioOne's Terms of Use, available at www.bioone.org/page/terms_of_use.

Usage of BioOne content is strictly limited to personal, educational, and non-commercial use. Commercial inquiries or rights and permissions requests should be directed to the individual publisher as copyright holder. 


\title{
DIFFERENT PATTERNS OF PARENTAL EFFORT DURING CHICK-REARING BY FEMALE AND MALE THICK-BILLED MURRES (URIA LOMVIA) AT A LOW-ARCTIC COLONY
}

\author{
IAn L. Jones, ${ }^{1,4}$ Sherrylynn Rowe, $, 1,5$ Steve M. CARr, ${ }^{1}$ GaIl Fraser,${ }^{2,6}$ AND \\ PHILIP TAYLOR ${ }^{3}$ \\ ${ }^{1}$ Department of Biology, Memorial University of Newfoundland, St. John's, Newfoundland A1B 3X9, Canada; \\ ${ }^{2}$ Biopsychology Program, Memorial University of Newfoundland, St. John's, Newfoundland A1B 3X9, Canada; and \\ ${ }^{3}$ Department of Biology, Acadia University, Wolfville, Nova Scotia B0P 1X0, Canada
}

\begin{abstract}
Using temperature loggers and radio telemetry, foraging and brooding behaviors of female and male Thick-billed Murres (Uria lomvia) were measured during chick rearing at the Gannet Islands, Labrador, to quantify parental roles during this crucial stage of reproduction. We recorded 2,725 foraging dives by 10 females and 7 males during 1,416 bird-hours of monitoring. Our study birds made between 21 and 107 dives per day between 0327 and 2220 hours, with $54 \%$ of females' dives and $<1 \%$ of males' dives occurring in conditions of low illumination between sunset and sunrise. Males foraged mostly at midday and, overall, made longer and presumably deeper dives (mean duration $116.2 \pm 37.6 \mathrm{~s}$ ) than females (mean duration $84.1 \pm 46.0 \mathrm{~s}$ ). The maximum dive duration recorded was $240 \mathrm{~s}$. Final dives of foraging trips were inferred to include dives during which chick meals ( $~ 95 \%$ by number daubed shanny [Lumpenus maculatus]) were obtained. Those dives (mean duration $134.0 \pm 36.1 \mathrm{~s}$ ) and dives in final diving bouts prior to return to the breeding site (mean duration $139.1 \pm 40.2 \mathrm{~s}$ ) averaged longer than other dives, and longer in males than in females, but there was no difference between the sexes in their daily frequency. The modal travel time from the last dive in a feeding trip to arrival at the breeding site was 8 min (no difference between sexes), which represents a maximum travel distance at $65 \mathrm{~km} \mathrm{~h}^{-1}$ of 8.7 $\mathrm{km}$, suggesting that foraging occurred close to the colony. Females spent $9 \mathrm{~h}$ day ${ }^{-1}(38 \%$ of day, mostly diurnal brooding) at breeding sites whereas males spent $16 \mathrm{~h}$ (67\% of day, mostly nocturnal brooding). Taken together, these data indicated drastic differences in patterns of foraging and brooding behavior between male and female Thick-billed Murres, but suggest that individual and intercolony variation were also significant. Received 4 September 2001, accepted 17 July 2002.
\end{abstract}

RÉSUMÉ.-À l'aide d'un enregistreur automatique de température et de la radio-télémétrie, les comportements de recherche alimentaire et d'élevage chez la femelle et le mâle du Guillemot de Brünnich (Uria lomvia) ont été mesurés au cours de l'élevage des jeunes aux Gannet Islands, Labrador, pour quantifier le rôle des parents au cours de cette étape crucial de la reproduction. Nous avons enregistré 2,725 plongées de quête alimentaire par 10 femelles et 7 mâles au cours de 1,416 heures-oiseau de suivi. Les oiseaux étudiés ont effectué entre 21 et 107 plongées par jour entre les heures 0327 et 2220 , avec $54 \%$ de plongées pour les femelles et $<1 \%$ de plongées pour les mâles qui se sont déroulées dans des conditions de faible luminosité entre le lever et le coucher du soleil. Les mâles recherchaient de la nourriture essentiellement en milieu de journée et, le plus important, ils effectuaient des plongées plus longues et vraisemblablement plus profondes (durée moyenne $116.2 \pm 37.6 \mathrm{~s}$ ) que les femelles (durée moyenne $84.1 \pm 46.0$ s). La durée de plongée maximale enregistrée a été de 240 s. Lors de la recherche alimentaire, les plongées finales ont été inférées pour inclure les plongées destinées au nourrissage des jeunes ( 95\% de Lompénie tachetée [Lumpenus maculatus] en nombre). Ces plongées (durée moyenne $134.0 \pm 36.1$ s) et les plongées précédent le retour au site de nidification (durée moyenne $139.1 \pm 40.2$ s) étaient plus longues en moyenne que les autres plongées. Elles étaient également plus long pour les mâles que pour les femelles, mais il n'y avait pas de différence entre les sexes dans leur fréquence journalière.

\footnotetext{
${ }^{4}$ E-mail: ijones@morgan.ucs.mun.ca

${ }^{5}$ Present address: Department of Biology, Dalhousie University, Halifax, Nova Scotia B3H 4J1, Canada.

${ }^{6}$ Present address: Department of Biology, York University, 4700 Keele Street, Toronto, Ontario M3J 1P3, Canada.
} 


\begin{abstract}
Le temps de voyage moyen de la dernière plongée d'un épisode de quête alimentaire à l'arrivée au site de nidification était de $8 \mathrm{~min}$ (aucune différence entre les sexes), ce qui représente une distance de voyage maximale de $8.7 \mathrm{~km}$ à la vitesse de $65 \mathrm{~km} \mathrm{~h}^{-1}$, suggérant que la recherche de nourriture avait lieu proche de la colonie. Les femelles ont passé $9 \mathrm{~h} \mathrm{jour}^{-1}$ (38\% du jour, élevage diurne principalement) au site de nidification alors que les mâles en ont passé 16 h (67\% du jour, élevage nocturne principalement). L'ensemble de ces données indiquaient des différences drastiques dans les patrons des comportements de recherche alimentaire et d'élevage entre le mâle et la femelle du Guillemot de Brünnich, et suggèrent que les variations individuelles et intercolonies étaient également significatives.
\end{abstract}

PATTERNS OF FEMALE and male parental effort during chick rearing in monogamous birds with obligate biparental care, such as seabirds, are interesting because parental effort may differ between the sexes due to a variety of constraints imposed by anatomical and behavioral ecological factors. Males' parental investment may be less than females' if their confidence of paternity is low (Winkler 1987), although that is unlikely to be a major factor in most seabird species because the frequency of extrapair fertilizations is thought to be low (e.g. Hunter et al. 1992; but see Wagner 1992). Even if female and male seabirds invest more or less equally in parental care, the form of their investment may be distributed unevenly over the incubation and chick-rearing periods, or they may use different foraging tactics to obtain food for chick provisioning. A clear quantification of female-male differences in patterns of parental effort within and among species is thus necessary to understand the evolution of parental care in seabirds. In this study, we investigated how patterns of foraging behavior and parental care differed between the sexes in a pursuitdiving monogamous seabird, the Thick-billed Murre (Uria lomvia).

Female and male diving seabirds such as some auks provision chicks on fish and invertebrates captured at sea far from breeding colonies, and with the availability of small electronic data loggers, there is a growing opportunity to quantify parents' foraging efforts at sea. A few studies have demonstrated differences in foraging and parental care behavior between female and male seabirds. Among penguin species, there is remarkable variation in relative contribution to incubation, brooding, and chick provisioning (Williams 1995). For example, chick brooding is shared equally with daily exchanges between male and female Magellanic (Spheniscus magellanicus) and Gentoo (Pygoscelis papua) penguins, undertaken by males alone in Rockhopper Penguins (Eudyptes chrysocome), and undertaken mostly by females in the Emperor Penguin ( $A p$ tenodytes forsteri; Williams 1995). Consequently, patterns of penguin chick provisioning also vary, with effort highly skewed to one sex during early chick rearing in some species (e.g. females alone provision small chicks in some, in others those duties are shared within breeding pairs; Williams 1995). Wandering Albatross (Diomedea exulans) females provision chicks with oceanic prey species, whereas males provisioned chicks with prey caught over the shelf edge and their cumulative efforts during chickrearing contributed prey with $50 \%$ greater energetic value than that delivered by females (Weimerskirch et al. 1997). Among auk species, female-male differences in parental care are less well known (Gaston and Jones 1998).

Thick-billed Murre chicks are brooded and provisioned at the colony by both sexes for 1530 days after which they are taken to sea by the male alone and cared for offshore (Gaston and Nettleship 1981, Gaston and Jones 1998). An evolutionary-ecological explanation for this diversion of parental roles after the chicks' colony departure is lacking. However, information on Thick-billed Murres' remarkable foraging behavior during the period when the chick is cared for at the colony is available from Coats Island, Canada (Croll et al. 1992); Latrabjarg, Iceland (Benvenuti et al. 1998); the Gannet Islands, Labrador (Bryant and Jones 1999); Hakluyt Island, Greenland (Falk et al. 2000); and Kongsfjorden, Svalbard (Mehlum et al. 2001). Although Thick-billed Murres are arguably the auk species with the best-quantified foraging activity during the breeding season, no previous study has compared time-activity budgets and diving behavior of females and males or directly addressed the origins of intersexual differences in patterns of parental investment.

In summary, the objectives of our study were to (1) quantify the diurnal timing and duration 
of brooding and diving by female and male Thick-billed Murres during chick-rearing, (2) identify and compare the duration and diurnal timing of females' and males' self-maintenance and chick-provisioning dives, (3) estimate the distance chick-provisioning females and males foraged from the colony, and (4) compare the foraging activity of Thick-billed Murres from the Gannet Islands, Labrador, to other populations for which information is available.

\section{Methods}

Field methodology.-Fieldwork was conducted at the Gannet Islands, Labrador ( $53^{\circ} 56^{\prime} \mathrm{N}, 56^{\circ} 32^{\prime} \mathrm{W}$ ) during August 1999. Relative to other North Atlantic colonies of Thick-billed Murres, the colony at the Gannet Islands is small (1,405 pairs in 1983; Birkhead and Nettleship 1987a) and likely increasing (G. Robertson and R. D. Elliot unpubl. data, I. L. Jones pers. obs.). Using capillary-tube maximum-depth recorders at the Gannet Islands, Bryant and Jones (1999) found that brooding and incubating Thickbilled Murres' modal maximum dive depth during 24-48 h deployments was $100 \mathrm{~m}$ (range 40-178 m). Thick-billed Murre chicks at that site were fed predominantly daubed shannys, a benthic fish, with small numbers of capelin (Mallotus villosus), sandlance (Ammodytes spp.), and Arctic cod (Boreogadus saida; Birkhead and Nettleship 1987b, Bryant et al. 1999). Ocean depth within $100 \mathrm{~km}$ of the Gannet islands is predominantly 30-200 m. We captured adult Thickbilled Murres as they brooded small chicks (approximately 1-4 days of age) using a monofilament noose attached to a $5 \mathrm{~m}$ graphite composite pole. We caught only single members of a breeding pairs, between 1100 and 1900 AST between 5-12 August. Each bird was held for $\sim 5$ min while we attached a radio transmitter (secured to stainless steel leg band) and a StowAway TidbiT (Onset Computer Corporation, Bourne, Massachusetts) temperature logger (glued with "Hot Stuff"® cyanoacrylate adhesive to the mantle feathers). Most individuals flew directly to their breeding site and resumed brooding their chick immediately upon release; two birds flew to the sea but returned within $30 \mathrm{~min}$.

The function of radio telemetry was to precisely monitor each bird's breeding site attendance. The radio transmitters weighed $3 \mathrm{~g}(<0.5 \%$ of the birds' body mass, $<1 \mathrm{~cm}^{2}$ in cross-sectional area) and their frequencies ranged from 150.016 to $150.114 \mathrm{kHz}$, with pulse rates of 38 to 80 beats per minute. To minimize their effective range and minimize disturbance to the birds the radio transmitters were not equipped with external antennas. Two short range $(<5 \mathrm{~m})$ whip antennas were placed at either end of the ledge occupied by the study birds, each connected to a Lotek (Newmarket, Ontario) SRX 400 radio receiver by 15 m coaxial cables. The SRX 400 automatically logged the presence of each bird at its ledge breeding site at $3 \mathrm{~min}$ intervals. This system allowed us to continuously monitor individuals' presence or absence at its breeding site $24 \mathrm{~h}$ per day during chick rearing, indicating when each marked bird arrived at its breeding site, the time present at breeding site, and times of departure from the breeding site with a resolution of $\sim 3 \mathrm{~min}$. For the two birds for which no radio telemetry data were available, we inferred time arrival and presence at the colony based on abrupt temperature shifts to $>12^{\circ} \mathrm{C}$ (see below).

The function of temperature loggers was to precisely record diving behavior. Each $17 \mathrm{~g}$ ( $\sim 2 \%$ of body mass, $4.5 \mathrm{~cm}^{2}$ cross-sectional area) TidbiT logger recorded temperature to $\pm 0.2^{\circ} \mathrm{C}$ and date and time to $\pm 1 \mathrm{~min}$ per week every $10 \mathrm{~s}$ for up to $90 \mathrm{~h}$ $(32,520$ measurements). Loggers were set to commence recording $12 \mathrm{~h}$ after capture to minimize any disturbance effects. These inexpensive loggers provided no direct measure of dive depth but did allow us to quantify the timing and duration of dives and estimate sea water temperature at the depths achieved. We began attempts to recapture each bird at the latest on the fifth day after initial capture. Each recaptured bird was held for $<5$ min while the telemetry gear was gently removed and a small blood sample was taken from the brachial vein for sexing ( $n=11$ birds; Fridolfsson and Ellegren 1999).

We conducted eight $4 \mathrm{~h}$ feeding watches (1400 to 1800 hours) using a $20 \times$ telescope to quantify Thickbilled Murre chick diet on a study area close to the telemetry birds (for further details see Bryant et al. 1999, Bryant and Jones 1999). For each food delivery, we recorded the time, site number, and species of prey delivered.

Data analysis and interpretation.-Data from the radio telemetry receiver-logger and the temperature loggers were used to reconstruct birds' activity at sea and presence at breeding sites. Mean air temperature near the sea surface during the study period was 10.3 $\pm 3.4^{\circ} \mathrm{C}(n=425$ measurements, range 7.2-27.9). Mean sea surface temperature recorded by a TidbiT logger attached to a buoy anchored near the Gannet Islands was $4.4 \pm 2.9^{\circ} \mathrm{C}(n=233$ measurements, range $0.4-7.9$ ). Sea temperatures at $10 \mathrm{~m}$ depth were close to $-1^{\circ} \mathrm{C}$. Temperature data from TidbiT loggers attached to foraging birds showed periods of stable readings at $\sim 10^{\circ} \mathrm{C}$ (close to the ambient air temperature) with intermittent series of abrupt shifts in temperature to or below $0^{\circ} \mathrm{C}$ (close to sea temperature at depth; Fig. 1). Each of these events was interpreted as a dive, with the first inflection point indicating the time the bird submerged (start of dive) and the second inflection point, when the temperature abruptly increased, indicating the time the bird resurfaced (end of dive). From those data we extracted for each dive for each bird: start time, end time, duration (end time minus start time), and minimum 


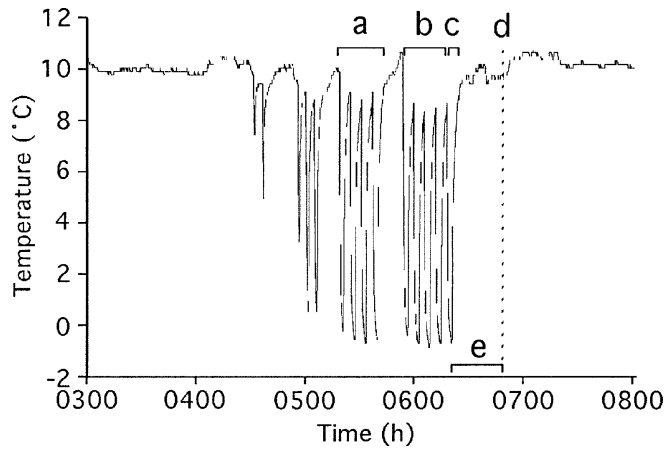

FIG. 1. Temperature record from Thick-billed Murre 1 (female) for the morning of 8 August 1999, showing dives classified as "self-feeding" (a), "provisioning bout" (b), or "provisioning dive" (c), based on arrival time at colony $(\mathrm{d})$, inferred from radio telemetry, and inferred "travel time" (e).

temperature. Dives with durations less than $20 \mathrm{~s}$ were not detectable. We were not able to distinguish time spent flying from time resting on the sea surface. Temperatures recorded by the loggers during birds' presence at the breeding site varied from $12^{\circ} \mathrm{C}$ to over $37^{\circ} \mathrm{C}$. A foraging trip was defined as any period of absence from the colony during which at least one dive was detected.

We were unable to conduct continuous watches of the study birds, so each arrival at the breeding site (as indicated by radio telemetry) following a foraging trip at sea (as indicated by diving activity recorded by temperature loggers) was inferred as a possible chick provisioning event. That assumption was supported by observations at nearby murre breeding ledges in which individuals returning to the breeding site after foraging trips often (but not always) delivered a chick meal (Bryant 1998, Bryant et al. 1999). However, our assumption unavoidably included some final dives in which prey was not delivered as a possible chick provisioning dive. Events where the last dive was not directed for chick provisioning or when prey items intended for chicks were lost after the final dive but before the adult returned to the colony were not detectable. Dives were classified (Fig. 1) as (1) self-maintenance (all dives in bouts not followed by return to breeding site), (2) possible chick-provisioning bout (all dives in bouts directly followed by a return to breeding site), or (3) possible chick-provisioning dive (the final dive before return to breeding site). "Dive bouts" were defined as groups of four or more dives followed by a surface interval of $>4 \mathrm{~min}$. It was assumed that only the last dive in a bout could be the one during which a chick meal was obtained because murres invariably delivered a single fish to their chicks, held in the throat (Bryant et al. 1999), precluding further foraging. A maximum "travel time" was estimated based on the time elapsed between the end of the last dive (indicated by temperature logger) and time of arrival at the breeding site (from radio telemetry; Fig. 1). That time would include time spent flying back to the colony and any resting time after the final dive. Previous work with flight recorders has shown that Thick-billed Murres made few stops during their return flight back to the colony (Benvenuti et al. 1998, Falk et al. 2000). Measuring outbound flight times was not attempted because birds could engage in a variety of activities after departing the breeding site before beginning foraging.

We investigated two questions about individuals diurnal patterns of foraging and colony attendance: (1) Did individuals exhibit a diurnal pattern (e.g. consistently brooding at night and foraging by day, or vica versa, over $90 \mathrm{~h}$ of monitoring)?, and (2) Did the diurnal pattern vary consistently between sexes? A previous study found a sex-limited diurnal colony attendance pattern (males brood chicks mostly at night, females during the day; Gaston and Nettleship 1981). We confirmed the inferred sex for $n=10$ of our study birds using a molecular sexing technique (Fridolfsson and Ellegren 1999). That method examined a locus (chromo-helicase-DNA binding protein, CHD) that is present as a pair of duplicated gene loci, one in the homologous pseudoautosomal portion of the $\mathrm{W}$ and $\mathrm{Z}$ chromosomes and a second in the $\mathrm{Z}$ specific portion of the $\mathrm{Z}$ chromosome. The two loci have conserved exon structures but differ in their intron lengths. Enzymatic amplification of genomic DNA thus results in a two-band pattern in females $(\mathrm{ZW})$ and a single-band pattern in males (WW). This method avoided the problem of false negatives.

\section{Results}

Frequency, diurnal timing, and duration of dives.-We recovered telemetry gear from 17 of the 22 Thick-billed Murres originally captured (four temperature loggers detached soon after initial capture and one bird was not seen again after initial capture). On the basis of telemetry data, 10 birds brooded chicks only during daylight hours (foraging mostly close to dawn and dusk), and 7 birds brooded their chick each night (foraging mostly at midday) of monitoring. Among the individuals whose sex was confirmed using the genetic technique (10 of 11 samples; Fridolfsson and Ellegren 1999), the day-brooding birds were females $(n=5)$ and the night-brooding birds were males $(n=5)$. Similar patterns were observed for additional males and females (sexed using the genetic technique) at the Gannet Islands during August 2000 (R. Paredes unpubl. data). Therefore, 
TABLE 1. Summary information for Thick-billed Murres monitored with telemetry equipment at Gannet Islands during August 1999.

\begin{tabular}{|c|c|c|c|c|c|}
\hline Sex & $\begin{array}{l}\text { Moni- } \\
\text { tored } \\
\text { (hours) }\end{array}$ & $\begin{array}{l}\text { Forag- } \\
\text { ing } \\
\text { trips }\end{array}$ & $\begin{array}{l}\text { Dives } \\
(n)\end{array}$ & $\begin{array}{l}\text { Dive duration } \\
\text { (s), mean } \pm S D\end{array}$ & $\begin{array}{l}\text { Lon- } \\
\text { gest } \\
\text { dive } \\
\text { (s) }\end{array}$ \\
\hline $\mathrm{Fa}^{\mathrm{a}}$ & 83.2 & 5 & 214 & $79.8 \pm 38.6$ & 200 \\
\hline $\mathrm{Fa}^{\mathrm{a}}$ & 82.3 & 3 & 162 & $74.4 \pm 26.9$ & 200 \\
\hline $\mathrm{F}^{\mathrm{b}}$ & 90.3 & 9 & 229 & $91.6 \pm 58.3$ & 220 \\
\hline $\mathrm{F}^{\mathrm{b}}$ & 90.3 & 10 & 173 & $89.3 \pm 58.5$ & 200 \\
\hline $\mathrm{F}^{\mathrm{b}}$ & 83.2 & 5 & 57 & $122.8 \pm 50.4$ & 190 \\
\hline $\mathrm{F}^{\mathrm{b}}$ & 90.3 & 5 & 225 & $76.5 \pm 38.1$ & 170 \\
\hline $\mathrm{Fb}^{\mathrm{b}}$ & 90.3 & 14 & 249 & $87.2 \pm 55.9$ & 240 \\
\hline $\mathrm{F}^{\mathrm{b}}$ & 90.3 & 4 & 116 & $82.0 \pm 30.2$ & 150 \\
\hline $\mathrm{Fa}^{\mathrm{a}}$ & 81.8 & 6 & 143 & $83.1 \pm 29.7$ & 170 \\
\hline $\mathrm{Fa}^{\mathrm{a}}$ & 79.1 & 4 & 75 & $67.7 \pm 28.2$ & 160 \\
\hline $\mathrm{M}^{\mathrm{b}}$ & 40.6 & 5 & 112 & $63.5 \pm 40.2$ & 190 \\
\hline$M^{b}$ & 89.1 & 9 & 176 & $113.0 \pm 34.4$ & 181 \\
\hline$M^{a}$ & 90.3 & 8 & 173 & $111.3 \pm 14.7$ & 140 \\
\hline $\mathrm{M}^{\mathrm{a}}$ & 79 & 10 & 171 & $112.1 \pm 26.9$ & 160 \\
\hline $\mathrm{M}^{\mathrm{b}}$ & 82.2 & 9 & 124 & $144.1 \pm 35.9$ & 220 \\
\hline $\mathrm{M}^{\mathrm{b}}$ & 86.5 & 6 & 156 & $123.8 \pm 27.1$ & 180 \\
\hline $\mathrm{M}^{\mathrm{b}}$ & 86.7 & 13 & 174 & $135.4 \pm 35.8$ & 210 \\
\hline
\end{tabular}

a Inferred from timing of chick brooding.

${ }^{\mathrm{b}}$ Inferred from genetic sexing technique (Fridolfsson and Ellegren 1999).

we inferred the remaining seven individual's sex based on timing of brooding (by night, males; by day, females). Overall, we recorded 2,725 dives during 125 foraging trips by the 10 females and 7 males during 1,416 bird-hours of monitoring (Table 1). Our study birds made between 21 and 107 dives per day, with no significant difference in number of dives per day between sexes (females, mean $=52 \pm 21$, range 22-107; males, mean $=42 \pm 13$, range $21-64 ; F$ $=1.5, \mathrm{df}=1$ and $15, P=0.24)$. Similarly, there was no significant difference in the number of dives per trip between the sexes (females, mean $=26 \pm 22$, range 1-92; males, mean $=18 \pm 15$, range $1-56, F=4.1, \mathrm{df}=1$ and $15, P=0.06$ ). There was no correlation between return travel time of last dives in a foraging trip and duration of these dives $(r=0.07, n=116, P=0.5)$, providing no indication that dives were of different duration or depth in different foraging areas.

No dives were recorded during the $5.1 \mathrm{~h}$ period of darkness between 2220 (119 min after sunset) and 0327 (112 min before sunrise; Fig. 2 ). During that time period, males were invariably at the breeding site brooding the chick, whereas females remained at sea, but inactive (as indicated by stable temperature readings at

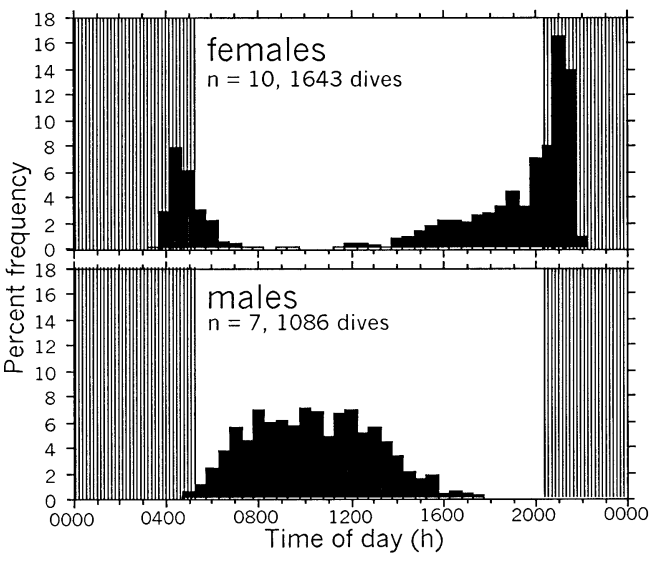

FIG. 2. Diurnal timing of all dives by female and male Thick-billed Murres; shaded areas indicate times after sunset and before sunrise.

$8-10^{\circ} \mathrm{C}$ ). Female dives occurred predominantly near dawn and dusk $(889 / 1,643$ or $54 \%$ occurred after sunset and before sunrise), whereas male dives occurred predominantly during the day (only $3 / 1,086$ or $<1 \%$ occurred after sunset and before sunrise; Fig. 2).

Males' modal dive duration was close to 2 min throughout the day, whereas females' dives varied in duration according to time of day (Fig. 3). We performed a repeated-measures ANOVA, with sex and time of day relative to solar noon as factors and we found significant main effects of sex $(F=30.7, \mathrm{df}=1$ and $13, P=0.0001)$ and time of day $(F=6.5, \mathrm{df}=$ 1 and $13, P=0.03$ ), and a significant sex $\times$ time-of-day interaction term $(F=5.4, \mathrm{df}=1$

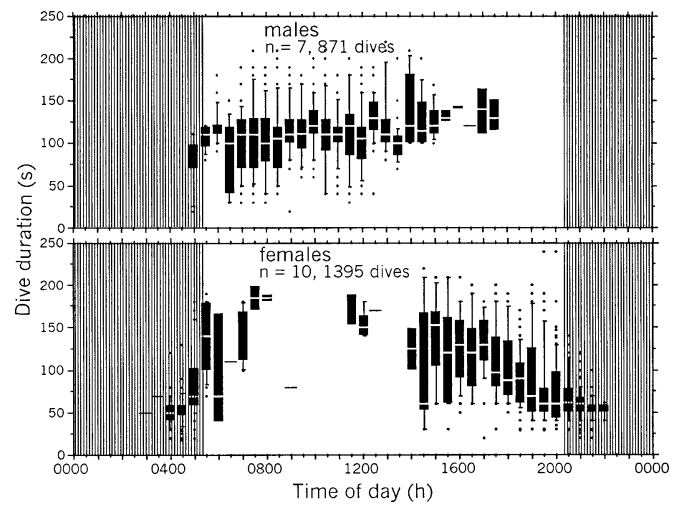

FIG. 3. Box plots indicating durations of selfmaintenance dives by female and male Thick-billed Murres relative to time of day (box plot shows 10th, 25th, 50th, 75th, and 90th percentiles and outliers). 


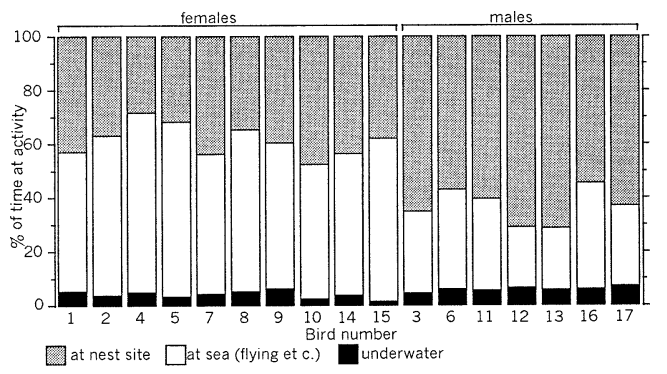

FIG. 4. Time activity budgets for 10 female and 7 male Thick-billed Murres rearing chicks at Gannet Islands, Labrador.

and $13, P=0.04)$. We performed the same analysis on a subset of data including only times of day when information was available for both sexes; for those (few) data, there was no effect of $\operatorname{sex}(F=1.4, \mathrm{df}=1$ and $13, P=0.3)$, there was a significant effect of time of day $(F=8.9$, $\mathrm{df}=1$ and $13, P=0.01)$, but the sex $\times$ time of day interaction term was not significant $(F=$ $4.2, \mathrm{df}=1$ and $13, P=0.06$ ). Thus males' dives tended to be longer and presumably deeper than females', but that was strongly influenced by the time-of-day effect. Females' dives after sunset and before sunrise (most of their dives) were shorter than dives that occurred during daylight hours (mean of all individuals' average dive durations by night $61.9 \pm 8.5$ [SD] s, by day $113.0 \pm 22.0 \mathrm{~s}$; Fig. 3). Overall, males and females spent a similar proportion of their time engaged in dives (mean of all males' average daily time underwater $4904 \pm 790$ [SD] s (5.7\% of day), mean for females $4,514 \pm 1,753 \mathrm{~s}$ (5.2\% of day), $F=1.1, \mathrm{df}=1$ and $15, P=0.3$; Fig. 4).

Characteristics of possible chick-provisioning dives. -We recorded 117 dives (2-13 from each of 17 birds) that were followed directly by the bird returning to its breeding site. Duration of dives was influenced by both sex $(F=23.1$, df $=1$ and $15, P=0.0005$ ) and type of dive (chick provisioning vs. chick bout vs. self maintenance; $F=5.4, \mathrm{df}=2$ and $15, P=0.024)$. Possible chick-provisioning dives (mean duration $134.0 \pm 36.1 \mathrm{~s}$ ) and dives during possible chickprovisioning bouts (mean duration $139.2 \pm$ $40.2 \mathrm{~s}$ ) were longer in duration than self-maintenance dives (mean duration $88.1 \pm 42.0 \mathrm{~s}$ ) There was no statistically significant difference in the daily frequency of potential chick provisioning dives between males $(8.6 \pm 7.0$ dives,

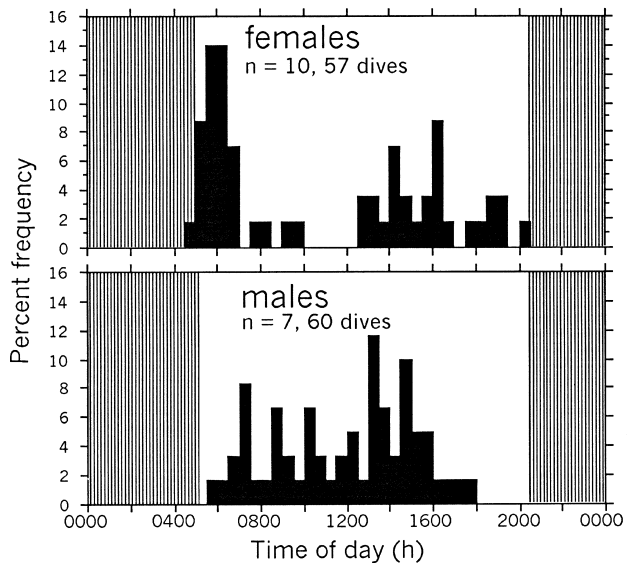

FIG. 5. Diurnal timing of chick provisioning dives by female and male Thick-billed Murres; shaded areas indicate times after sunset and before sunrise.

range $1-20, n=60$ dives) and females (5.7 \pm 8.5 dives, range $2-10, n=57$ dives). That inferred provisioning frequency was higher than the generally observed provisioning rate for this species (2-5 fish per day; Gaston and Jones 1998) because individuals did not provision their chicks after every foraging trip. We believe the rate of our possible chick provisioning dives ( $\sim 15$ per day per pair) was about double the rate of chick feeds at the Gannet Islands, so about half the recorded possible chick provisioning dives either were not intended for chick provisioning or the prey items were lost before the adult returned to the colony. Possible chickprovisioning dives terminated bouts of $4.2 \pm$ 3.2 dives (range 1-13) with no difference between sexes $(F=7.9, \mathrm{df}=1$ and $15, P=0.01)$ in number of dives in chick-provisioning bouts. The duration of possible chick provisioning dives was greater in males than in females $(F=$ 9.03, $\mathrm{df}=1$ and $15, P=0.009)$. The individual with the longest chick-provisioning dives had a mean duration of $165.1 \pm 19.0 \mathrm{~s}$ (range 130190); the individual with the shortest mean dive duration, $101.4 \pm 24.2 \mathrm{~s}$ (range 50-130). The diurnal timing of females' and males' chick-provisioning dives were similar to that of their self-maintenance dives: bimodal activity by females during morning and evening and a single activity peak for males during early afternoon (Fig. 5).

Travel time for chick-provisioning.-The time elapsed from the last dive in a foraging trip to 


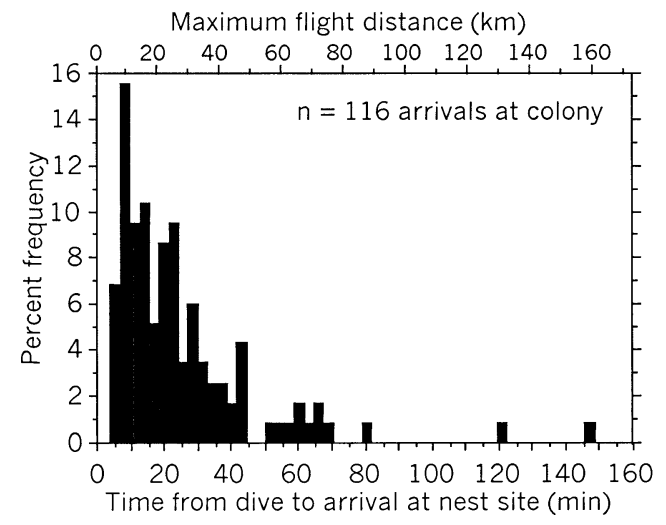

FIG. 6. Travel times for 116 chick provisioning dives to return to breeding site, with corresponding estimated maximum travel distance assuming a flight speed of $65 \mathrm{~km} \mathrm{~h}^{-1}$.

return to breeding site varied from 4-149 $\mathrm{min}$ (Fig. 6), with no difference between sexes $(F=$ $0.6, \mathrm{df}=1$ and $15, P=0.4)$. However, travel durations did vary significantly among individuals $(F=2.1, \mathrm{df}=16$ and $99, P=0.02)$. The individual with the longest travel durations had a mean duration of $63.0 \pm 28.6 \mathrm{~min}$ (range 30 149); the individual with the shortest mean travel duration, $11.4 \pm 3.0 \mathrm{~min}$ (range $7-23$ ). The overall modal maximum travel time was 8 min, representing a maximum travel distance at $65 \mathrm{~km} \mathrm{~h}^{-1}$ (Benvenuti et al. 1998) of only 8.7 $\mathrm{km}$ (Fig. 6). About half of all return trips involved a travel time of $<20 \mathrm{~min}(21.7 \mathrm{~km}$ maximum travel distance). The overall estimated mean maximum travel distance for the 116 return flights was $26.7 \pm 23.6 \mathrm{~km}$ (range $4.3-$ 160.9).

Brooding.-Telemetry indicated that females spent an average of $9.2 \pm 1.6 \mathrm{~h}$ per day (range 6.9-12.5 $\mathrm{h}, n=10$ ) at their breeding sites; males spent $16.0 \pm 1.4 \mathrm{~h}$ per day (range 13.9-18.9 $\mathrm{h}$, $n=7$; Fig. 4). Males typically brooded the chick starting in the late afternoon (1400 to 1800 hours), through the hours of darkness, to the early morning several hours after first light (0630 to 0900 hours). Females were never present at the breeding site after dark; males were never present at the breeding site for more than an hour at a time near mid-day. The difference between the sexes in time at site was statistically significant $(F=14.4, \mathrm{df}=1$ and $15, P=$ 0.002).
Chick diet.-We observed Thick-billed Murres (unknown sex) delivering 222 chick meals, including 208 daubed shannys $(94.7 \%), 8$ sandlance $(3.6 \%)$, and 6 capelin $(2.7 \%)$ during the study period. The timing of feeding watches (1400-1800 h) coincided with a nearly equal proportion of female and male chick-provisioning dives (17:18, respectively), but obviously did not record morning and late evening chick-provisioning activity. On the basis of watches conducted during all daylight hours at our study site in 1996-1997, chick meal composition by prey species varied little by time of day (Bryant 1998).

\section{DisCUSSION}

Effect of telemetry gear on study birds.-As in other studies using similar capture methodology, our study birds returned to their breeding sites immediately or soon after release and resumed brooding their chicks, which suggests that the level of disturbance caused by capture and installation of the telemetry gear was low. Temperature loggers and radio transmitters would be expected to have a cost to the birds in terms of extra mass and aerodynamic and hydrodynamic drag during flights to foraging areas and during underwater foraging. However, chick-provisioning rates inferred in our study birds were similar or higher to those of undisturbed birds at the Gannet Islands, apart from one bird that disappeared after capture and a second bird that lost its chick for unknown reasons after its temperature logger was full but before recapture. All our study birds continued brooding and provisioning their chicks after the removal of telemetry gear. Furthermore, the size and mass of the gear used in our study was low (20 g) compared to that used in previous studies (e.g. $35 \mathrm{~g}$, Croll et al. 1992; 29 g, Benvenuti et al. 1998; 28.5 g, Falk et al. 2000). Taken together, these observations suggest that disturbance caused by our telemetry equipment was unlikely to affect the interpretation of the birds' activities.

Thick-billed Murre diving activity compared to other areas.-Among published studies of Thick-billed Murre foraging behavior, this study concerned birds breeding at relatively low latitude $\left(53^{\circ} \mathrm{N}\right)$ with about an $8.5 \mathrm{~h}$ period between sunset and sunrise, including a $5.1 \mathrm{~h}$ period when it was apparently too dark for any 
underwater foraging to occur and there was minimal activity at the colony. The observation that dives were progressively longer in duration after dawn and progressively shorter towards dusk (Fig. 3) further supports the idea that timing of Thick-billed Murres foraging near the Gannet Islands was constrained by lack of available light. In three previous studies (Coats Island, $63^{\circ} \mathrm{N}$; Latrabjarg, $65^{\circ} \mathrm{N}$; Hakluyt Island, $77^{\circ} \mathrm{N}$ ), foraging took place throughout the day and night and peaked in intensity near midnight when ample light remained available for foraging. That has obvious consequences for day-brooding versus night-brooding individual birds at our Labrador colony compared to colonies at higher latitiudes. Thick-billed Murres at the Gannet Islands have less time to forage per day and day-brooding female individuals may be inconvenienced by the necessity to forage mostly before sunrise and after sunset.

Our measures of diving behavior at the Gannet Islands are comparable to those of Croll et al. (1992) from Coats Island and Falk et al. (2000) from Hakluyt Island because all studies focused on birds provisioning chicks and recorded diurnal timing and duration of dives. Limitations of the data-logging equipment used in all studies were likely to affect comparability of our Gannet Islands data with other studies. Our loggers used temperature recorded every $10 \mathrm{~s}$ to indicate dives, so we did not record dives of $<20 \mathrm{~s}$ duration. Croll et al.'s (1992) loggers recorded depth every $4 \mathrm{~s}$, but dives shallower than $3 \mathrm{~m}$ were not recorded. Falk et al.'s (2000) loggers also recorded depth every $4 \mathrm{~s}$, but duration of dives shallower than $2 \mathrm{~m}$ were not recorded. All of those methods would tend to underestimate the frequency of short duration, shallow dives. Nevertheless, all three studies' methodology is likely comparable over most of the range of dive depths and durations for this species. The sex of Croll et al.'s (1992) and Falk et al.'s (2000) study birds was unknown. If the sex differences in foraging and brooding behavior observed at the Gannet Islands by us apply to other areas, the observed timing and duration of dives reported in previous studies would have been influenced by the ratio of females and males sampled.

Despite these methodological differences among studies, significant differences in diving and foraging behavior are apparent, likely based on prey species available and ocean depth near the different colony locations (Table 2). Modal dive duration at both the Gannet Islands and Coats Island were close to $1 \mathrm{~min}$, but there appeared to be more dives in the 120-200 s range at the Gannet Islands (Fig. 7), possibly because Gannet Islands birds foraged for their chicks (Bryant et al. 1999) and possibly themselves (I. L. Jones pers. obs.) principally on one benthic fish species, the daubed shanny. Birds at Hakluyt Island in high Arctic Greenland appeared to be "working harder" than birds at Coats and the Gannet Islands, because their dives averaged longer in duration and greater in depth compared to the other colonies (Table 2 ) and the maximum distance traveled from the colony was greater at Hakluyt Island than at the Gannet Islands (Falk et al. 2000). Combined with effect of latitude on available light and varying ocean depth near different murre colonies, a variety of environmental factors would appear to necessitate significant differences in foraging behavior among different murre colonies. The colony size at the Gannet Islands (1,405 pairs of Thick-billed Murres and 63,087 pairs of Common Murres [U. aalge]; Birkhead and Nettleship 1987a) was small compared to some other colonies studied, potentially affecting foraging behavior by reducing intra- and interspecific competition for prey (see Bryant and Jones 1999), although there were not obvious differences in the size of prey taken at the Gannet Islands compared to other areas (Bryant et al. 1999). One of the most notable findings of our study was the short distance the birds foraged from their breeding sites (modal maximum distance was $8.7 \mathrm{~km}$, the estimate allowing for no rest time after the last dive before return). That finding was also consistent with reduced competition for prey at our study site.

Differences between chick-provisioning dives and self-maintenance dives. - Most large auk species are thought to forage for relatively large energetically rich food items for chick provisioning (e.g. fish such as capelin, sandlance, or herring [Clupea harengus]) while seeking out smaller, more abundant, but less energetically rich food items (e.g. zooplankton such as euphausiids, and juvenile fish) when foraging for themselves during the breeding and nonbreeding season (Ydenberg 1994, Gaston and Jones 1998, Davoren and Burger 1999, Rowe et al. 2000). Our observations in this study were consistent with 


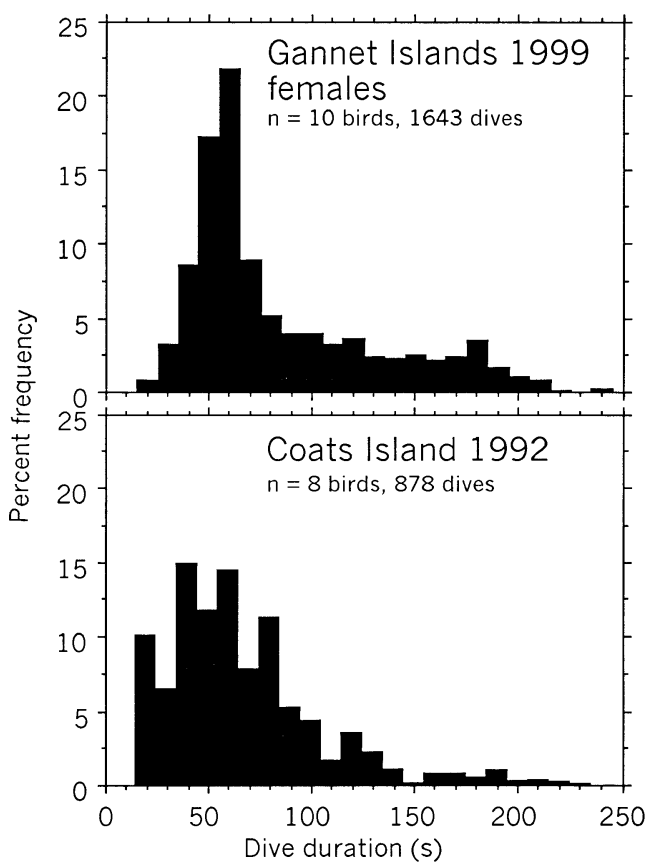

FIG. 7. Dive durations for Thick-billed Murres at the Gannet Islands, Labrador, and Coats Island, Northwest Territories (Croll et al. 1992).

such a pattern of foraging. Overall, potential chick-provisioning dives by our study birds were $>50 \%$ longer in duration than self-maintenance dives, consistent with those dives being directed towards benthic daubed shannys with which chicks were predominantly provisioned. Females' foraging activities were particularly distinct in that respect. Their selfmaintenance dives took place during the late afternoon and near dawn and dusk, were short in duration (frequently $<1 \mathrm{~min}$ ) compared to potential chick-provisioning dives, occurred in rapid succession (Fig. 3), and may have been directed towards diurnally migrating zooplankton, which would be closest to the sea surface at that time. Males never showed the pattern of short-duration dives in rapid succession exhibited by females, possibly because of the diurnal timing of their foraging activities during chick rearing.

Parental roles of female and male Thick-billed Murres during chick rearing.-Because females and males brooded chicks and foraged at sea at different times of day, we found evidence for major differences in parental investment in provisioning and parental care while chicks 
were at the colony. In terms of the most crucial foraging parameters-daily frequency of dives and duration of individual dives-we found clear differences in the diurnal timing and magnitude of males' and females' parental effort. Males foraged around midday when light conditions were ideal for foraging in deep water $(>100 \mathrm{~m})$ and vertically migrating prey would be expected to be at its maximum depth. Because of that, males' dives were of longer duration. Females foraged intensely near dawn and dusk when light conditions were low and likely precluded deep-water foraging, but with the possible advantage of greater availability of vertically migrating prey which would be approaching the surface at that time. The greater mean duration of males' dives was offset somewhat by females' average greater number of dives made per day, and possibly by the more costly female activity of rapid diving in quick succession without intervening rest intervals during dawn and dusk. What functional explanation might be offered for the observed difference in activity patterns between males and females during chick rearing? We speculate that the observed pattern might somehow benefit both females (who are recovering from energetic and nutrient costs of recent egg production and thus might profit from the flexibility of dawn and dusk foraging and less time spent at the breeding site), whereas also benefiting males (who are about to depart to sea with the chick for a lengthy period of uniparental care and could profit from the extra time devoted to guarding the breeding site). More detailed study of male and female activity and energy budgets during chick rearing would be required to address those possibilities.

Both sexes' diurnal pattern of foraging was constrained by the time of day spend brooding the chick at the breeding site. Males spent considerably more time at the breeding site brooding the chicks than their mates; but that may have carried a low cost (and likely even an overall energetic advantage) because they brooded the chick at night (mostly 2220 to 0327 hours), when females remained at sea, but were not able to engage in foraging activity because of low light levels. Falk et al. (2000) estimated the energetic expenditure of brooding a chick at the colony at $28 \mathrm{~kJ} \mathrm{~h}^{-1}$, and of swimming on the sea surface at $55 \mathrm{~kJ} \mathrm{~h}^{-1}$. If those estimates are realistic, nocturnal energetic expenditure by females would have far exceeded that of males, perhaps offsetting the greater energetic expenditure males devoted to diving. However, that constraint on females would not be present at most colonies of Thick-billed Murres, which occur at high latitudes (Gaston and Jones 1998), where both sexes are able to forage at all hours of the day. The nocturnal-diurnal division of male and female brooding in this species could be an adaptation to high latitudes that disadvantages breeding pairs at low-latitude colonies. In Common Murres, which breed at generally lower latitudes than Thickbilled Murres, females and males are equally likely to undertake nocturnal chick brooding (Wanless and Harris 1986).

Falk et al. (2000) were able to model Thickbilled Murre daily energetic expenditure by estimating the costs and expenditures of brooding, surface swimming, diving, and flying, and found considerable individual variability. Because we were unable to discriminate between time flying and time on the sea surface using our telemetry gear, we were unable to fully model and compare energetic expenditure by males and females, and thus we were not able to fully compare parental effort in terms of energy expenditure. Although our estimates of travel times of flights returning to the colony did not differ between the sexes, it is possible that our study females and males foraged in different locations, consistent with the different diurnal timing and characteristics of their dives. Further research with additional gear that records dive depth, differentiates flying from resting on the sea surface, or telemetry that pinpoints foraging locations, would be required to test that possibility. Foraging distances and time spent in flight vary highly both among individuals and among different colonies of Common and Thick-billed murres (Wanless et al. 1988, Cairns et al. 1987, Monaghan et al. 1994, Benvenuti et al. 1998, Falk et al. 2000). Our results suggest that variation between the sexes in foraging behavior can be significant and needs to be considered in future studies.

\section{ACKNOWLEDGMENTS}

We are grateful to B. Veitch, J. Dussureault, S. Bin Muzaffar, and M. Button for assistance in the field, and to R. Cahill for logistic support. We benefited from discussions and comments on manuscript 
drafts from R. Bryant, G. Davoren, T. Gaston, F. Mehlum, S. Wilhelm, and K. Woo. This study was supported by the Atlantic Cooperative Wildlife Ecology Research Network, Canadian Wildlife Service/Natural Sciences and Engineering Research Council (NSERC) of Canada, Industrial Research Chair and NSERC Individual Research grants to I.L.J., and by the Northern Scientific Training Program of the Department of Indian Affairs and Northern Development, Canada.

\section{Literature Cited}

Benvenuti, S., F. BonadonnA, L. DALl'Antonia, AND G. GUDMUNDSSON. 1998. Foraging flights of breeding Thick-billed Murres Uria lomvia as revealed by bird-borne direction recorders. Auk 115:57-66.

BirkHEAD, T. R., AND D. N. NetTleship. 1987a. Ecological relationships between Common Murres, Uria aalge, and Thick-billed Murres, Uria lomvia, at the Gannet Islands, Labrador. I. Morphometrics and timing of breeding. Canadian Journal of Zoology 65:1621-1629.

BiRKHEAD, T. R., AND D. N. NetTleship. 1987b. Ecological relationships between Common Murres, Uria aalge, and Thick-billed Murres, Uria lomvia, at the Gannet Islands, Labrador. III. Feeding ecology of the young. Canadian Journal of $\mathrm{Zo}-$ ology 65:1638-1649.

BRYANT, R. 1998. Food resource use and responses to changes in prey availability by Common and Thick-billed murres (Uria aalge and U. lomvia) breeding at the Gannet Islands, Labrador. M.S. thesis, Memorial University of Newfoundland, St. John's.

BRYANT, R., AND I. L. JONES. 1999. Food resource use and diet overlap of Common and Thick-billed murres at the Gannet Islands, Labrador. Waterbirds 22:263-272.

BryANT, R., I. L. JONES, AND J. M. HipfNER. 1999. Responses to changes in prey availability by Common and Thick-billed murres at the Gannet Islands, Labrador. Canadian Journal of Zoology 77:1278-1287.

Cairns, D. K., K. A. Bredin, And W. A. MontevecCHI. 1987. Activity budgets and foraging ranges of breeding Common Murres. Auk 104:218-224.

Croll, D., A. J. Gaston, A. E. Burger, And D. KonNOFF. 1992. Foraging behavior and the physiological adaptation for diving in Thick-billed Murres. Ecology 73:344-356.

Davoren, G. K., And A. E. Burger. 1999. Differences in prey selection and behavior during self feeding and chick provisioning in Rhinoceros Auklets. Animal Behaviour 58:853-863.
FalK, K., S. Benvenuti, L. DALl'Antonia, K. KAMPP, AND A. RibOLINI. 2000. Time allocation and foraging behavior of chick-rearing Brünnich's Guillemots Uria lomvia in high-Arctic Greenland. Ibis 142:82-92.

FridolfsSON, A.-K., AND H. Ellegren. 1999. A simple and universal method for molecular sexing of non-ratite birds. Journal of Avian Biology 30: 116-121.

Gaston, A. J., And D. N. Nettleship. 1981. The Thick-billed Murres of Prince Leopold Island. Canadian Wildlife Service Monograph Series, no. 6. Ottawa, Ontario.

GAston, A. J., And I. L. Jones. 1998. The Auks: Alcidae. Oxford University Press, Oxford.

Hunter, F. M., T. Burke, AND S. E. WATts. 1992. Frequent copulation as a method of paternity assurance in the Northern Fulmar. Animal Behaviour 44:149-156.

Mehlum, F., Y. WAtAnUKI, AND A. TAKAhashi. 2001. Diving behavior and foraging habitats of Brünnich's Guillemots Uria lomvia breeding in the high Arctic. Journal of Zoology (London) 255: 413-423.

Monaghan, P., P. Walton, S. Wanless, J. D. UtTLEY, AND M. D. BuRNS. 1994. Effects of prey abundance on the foraging behavior, diving efficiency and time allocation of breeding Guillemots Uria aalge. Ibis 136:214-222.

Rowe, S., I. L. Jones, J. W. Chardine, R. D. Elliot, AND B. G. VeItch. 2000. Recent changes in the winter diet of murres (Uria spp.) in coastal Newfoundland waters. Canadian Journal of Zoology 78:495-500.

WAGNER, R. H. 1992. Behavioral and breeding habitat related aspects of sperm competition in Razorbills. Behaviour 123:1-26.

WANLESS, S., AND M. P. HARRIS. 1986. Time spent at the colony by male and female Guillemots Uria aalge and Razorbills Alca torda. Bird Study 33: 168-176.

WAnless, S., J. A. Morris, AND M. P. HARris. 1988. Diving behavior of Guillemot Uria aalge, Puffin Fratercula arctica and Razorbill Alca torda as shown by radio-telemetry. Journal of Zoology (London) 216:73-81.

Williams, T. D. 1995. The Penguins: Spheniscidae. Oxford University Press, Oxford.

WieMERSKIRCH, H. Y., Y. Cherel, F. CUENOT-CHAILLET, AND V. RIDOUX. 1997. Alternative foraging strategies and resource allocation by male and female Wandering Albatrosses. Ecology 78: 2051-2063.

WinKLER, D. W. 1987. A general model of parental care. American Naturalist 130:526-543.

YDENBERG, R. C. 1994. The behavioral ecology of provisioning in birds. Ecoscience 1:1-14.

Associate Editor: D. N. Nettleship 